DOI: $10.14394 /$ edufil.2019.0019

ORCID: 0000-0003-1712-8636

\title{
Geneza i główne funkcje religii w ujęciu Robina Dunbara
}

\author{
Paweł Łoś \\ (Uniwersytet Warszawski, Instytut Filozofii)
}

\section{Wstęp}

Słynny brytyjski antropolog i psycholog ewolucyjny Robin Dunbar ${ }^{1} \mathrm{w}$ swoich pracach wiele miejsca poświęca zjawisku religii - przede wszystkim jej ewolucyjnemu pochodzeniu oraz pełnionym przez nią funkcji, które stara się wyjaśnić na gruncie naturalizmu (wykorzystuje m.in. dostępne dane paleoantropologiczne, jak i dotyczące ewolucji ludzkiego umysłu w przeciągu kilkuset tysięcy lat). Wpisuje się on w nurt tych badaczy, którzy sądzą, że religia jednoznacznie pełni funkcje adaptacyjne (tzn. sprzyjała i nadal sprzyja przetrwaniu i reprodukcji człowieka).

Poglądy Dunbara stoją w opozycji szczególnie wobec tezy, że religia stanowi jedynie produkt uboczny innych, korzystnych dla przetrwania cech ludzkich. Taką tezę głoszą m.in. Scott Atran, Richard Dawkins, Pascal Boyer czy Daniel Dennett ${ }^{2}$. W ujęciu Dunbara ich analizy zjawiska religii są skażone błędnym za-

1 Robin Dunbar, ur. w 1947 r., profesor Uniwersytetu w Oksfordzie, autor znany szczególnie za sprawą książki Pchly, plotki a ewolucja języka, tłum. T. Pańkowski, Warszawa 2009, w której zaprezentował hipotezę na temat przyczyny pojawienia się ludzkiej mowy; jest też twórcą tzw. liczby Dunbara - liczby określającej maksymalny limit osób, z którymi jednostka ludzka jest w stanie utrzymywać kognitywnie efektywną znajomość (budowanie relacji koleżeńskich, przyjacielskich, zawodowych), wynosi ona około 150; współpracował również z innymi, znanymi ewolucjonistami, np. z Johnem Maynardem Smithem i Robertem Foleyem.

2 W jednej z dwóch przytaczanych w tym artykule prac Dunbara (nowszej) krytycznie odnosi się 
łożeniem, wedle którego religia (czymkolwiek by była z punktu widzenia biologicznej ewolucji) nie jest w stanie pełnić funkcji adaptacyjnych; ma o tym zaś świadczyć m.in. ich własny brak czucia religijnego i rzekomy brak ewidentnych dowodów na to, że religia wpływa na liczbę potomków ludzi religijnych w kolejnych generacjach w stosunku do ich liczby u ludzi bezreligijnych. Dunbar stara się badać zachowania religijne, niezależnie od tego, czy jakieś twierdzenia i przekonania religijne mogą zostać uznane za niespójne, nieracjonalne. Podkreśla on, że nie wolno z góry zakładać, że religia zupełnie „nie nadaje się” do bycia adaptacją w ścisłym biologicznym sensie. Choć badania zjawiska religii mają już pewną historię, to jednak w rzeczywistości jest to dopiero początek drogi. Spostrzeżenia i argumenty Dunbara na temat ewolucyjnego pochodzenia i funkcji religii mają za zadanie uzmysłowić badaczom z opozycyjnego obozu, że wbrew pozorom religia nie należy do zjawisk łatwo opisywanych i nie można pochopnie sprowadzać jej do bezużytecznego produktu ubocznego.

Celem niniejszego artykułu jest prezentacja poglądów Dunbara na religię ( $\mathrm{tj}$. jej genezę, istotę i funkcję) na gruncie antropologii ewolucyjnej, jak i też krytyczne rozważenie jego poglądów (tj. wskazanie i uzasadnienie, które jego tezy i argumenty są niepełne lub wydają się wręcz błędne).

\section{Archeologia religii}

Dunbar stwierdza, że nie jest obecnie możliwe określenie, kiedy religia pojawiła się w historii ludzkości; można formułować hipotezy na podstawie dostępnych danych archeologicznych, które stanowią pewne wskazówki, jednak nie istnieją jednoznaczne dowody ${ }^{3}$. Podkreśla on, że rewolucja okresu górnego paleolitu ograniczała się praktycznie do terytorium Europy; podobna zmiana nie wystąpiła - przynajmniej na taką samą skalę - wśród ówczesnych ludzi w Afryce, Azji i Australii. Jednak z drugiej strony wiadomo, że każda większa społeczność ludz-

on tylko wobec Boyera, który w znacznym stopniu podziela poglądy Atrana (i jedynie zdawkowo w przypisie); z drugiej strony ww. autorzy też nie odnosili się w swoich głównych pracach o religii wprost do koncepcji religii Dunbara. Zob. S. Atran, Ewolucyjny krajobraz religii, tłum. M. Kolan, Kraków 2013; P. Boyer, I człowiek stworzył bogów... Jak powstała religia?, tłum. K. Szeżyńska-Maćkowiak, Warszawa 2005; R. Dawkins, Bóg urojony, tłum. P.J. Szwajcer, Warszawa 2007; D.C. Dennett, Odczarowanie. Religia jako zjawisko naturalne, tłum. B Stanosz, Warszawa 2008.

3 Zob. R. Dunbar, Nowa historia ewolucji człowieka, tłum. B. Kucharzyk, Kraków 2014, s. 225. 
ka posiada jakąś formę religii, zatem początku religii trzeba szukać w czasach występowania wspólnego przodka wszystkich żyjących obecnie ludzi. Stąd też korzenie religii umiejscowić można w przedziale czasowym od ok. 70 tysięcy lat temu (gdy przodkowie Eurazjatów opuścili Afrykę - badania genetyki molekularnej dowodzą, że afrykańskie i eurazjatyckie gałęzie ludzi współczesnych były w tym czasie ostatni raz scalone) do ok. 200 tysięcy lat temu (gdy żył ostatni wspólny przodek wszystkich współczesnych ludzi), przy czym nie można wykluczyć, że religia pojawiła się jeszcze wcześniej, np. u neandertalczyków ${ }^{4}$.

Najważniejszy argument za istnieniem najstarszych zachowań religijnych dotyczy czasu sprzed kilkudziesięciu tysięcy lat (stanowią go zaplanowane pochówki, będące świadectwem wiary ludzi w istnienie życia po śmierci - pochówek jest tu rozumiany jako pogrzebanie człowieka razem z towarzyszącymi artefaktami $)^{5}$. Jak wskazuje Dunbar, „[t]rudno jest wyobrazić sobie powód, dla którego ktoś miałby poświęcać tyle troski grzebaniu zmarłych, jeśliby nie wierzyć w życie pozagrobowe. Dlaczego właściwie nie pozostawić po prostu ciała w lesie albo w naturalnej studni na tyle jaskini [...]?”. Zaznacza też, że planowane pochówki były bardzo powszechne w okresie górnego paleolitu. Uzasadnia to, wskazując na fakt, że ich liczba w porównaniu z kilkakrotnie dłuższym okresem środkowego paleolitu jest znacznie większa, a ponadto w górnym paleolicie różnią się one tym od wcześniejszych, że zwykle ciało było ułożone w ziemi płasko na plecach, tzn. inaczej niż w okresie środkowego paleolitu, gdy bezładnie wrzucano je do grobu - dotyczy to również neandertalczyka. Wiele grobów z górnego paleolitu zawierało też w obfitości czerwoną ochrę (często na głowie lub/i miednicy, kościach czy w okolicznej glebie), co zapewne wiązało się z rytualnym dekorowaniem ciała, podobnie jak obecnie w tradycyjnych społeczeństwach służy do tego właśnie ochra?

Dunbar zwraca uwagę na to, że wiele pochówków z okresu 30-20 tysięcy lat temu wykazuje się wręcz sporym wyrafinowaniem. Niektóre groby zlokalizowano w trudno dostępnych miejscach, np. w wiecznej zmarzlinie, co musiało wiązać się z ogromnym wysiłkiem wykonawczym i organizacyjnym. Do artefaktów, jakie umieszczano wtedy w grobach przy osobach zmarłych, zalicza się między innymi biżuterię, figurki z kości słoniowej, różne narzędzia, broń (jak np. osz-

Zob. tamże, s. 225-226.

Zob. R. Dunbar, Człowiek - biografia, tłum. Ł. Lamża, Kraków 2016, s. 303.

Tamże.

Zob. tamże, s. 303-304. 
czepy czy lance), muszle, rogi oraz zęby zwierząt (w górnym paleolicie aż około dwie trzecie grobów miało w swoim wnętrzu drogocenne naszyjniki i diademy). Liczna obecność znaczących artefaktów w grobach ma sugerować, że, wedle osób dokonujących pochówku, zmarli będą ich potrzebować w życiu pozagrobowym ${ }^{8}$. Groby z tego okresu charakteryzują się też tym, że często są zbiorowe (archeolodzy odkryli głównie groby kilkuosobowe, ponadto zdarzył się grób zawierający 18 osób, pochowanych w różnym czasie) ${ }^{9}$.

Jak zauważa Dunbar:

Tego typu wspólne pochówki w zasadzie nie są znane przed górnym paleolitem. Wydają się one wskazywać na istnienie wiary we wspólne wybieranie się zmarłych w to samo miejsce w zaświatach lub, w przypadkach, gdy zmarli umieszczani byli w grobie niejednocześnie [...], na dołączanie do wcześniej umarłych osób ${ }^{10}$.

Zdaniem autora takie cechy zaplanowanego pochówku ludzi oznaczają, że była wtedy obecna wiara $\mathrm{w}$ istnienie świata duchowego, do którego udają się zmarli i który można odwiedzać w stanie transu; taka wiara mogła istnieć znacznie wcześniej aniżeli w okresie górnego paleolitu (tj. okres 25 tysięcy lat wstecz stanowi tylko dolną granicę, tak więc nie wyklucza się jej pojawienia dziesiątki tysięcy lat wcześniej). Dunbar zaznacza, że taką wiarę znajduje się wyłącznie u ludzi anatomicznie współczesnych (tzn. kromaniończyków i ich potomków, żyjących dzisiaj ludzi; wiele oto wskazuje, że nie ma jej np. u neandertalczyka z uwagi na brak u niego wyrafinowanych pochówków; a jeżeli ją już posiadał, to w bardzo prostej formie) ${ }^{11}$.

Choć Dunbar dopuszcza istnienie wiary w świat duchowy wcześniej niż 30 tysięcy lat temu, to stwierdza także, że wszystkie cmentarne artefakty sugerują, iż prawdziwe przeczucie życia po śmierci pojawiło się dopiero u kromaniończyka w okresie górnego paleolitu. Potwierdzać ma to zaś datowanie wytworów sztuki prehistorycznej u ludzi - kobiecych figurek („posążków Wenus”) oraz rzeźb zwierząt, których wiek większości z nich jest szacowany w przedziale 28-21 tysięcy lat ${ }^{12}$. Zauważa także:

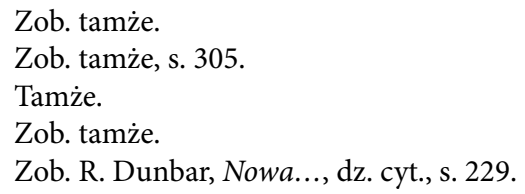


Cel całej tej sztuki pozostaje niejasny, ale fakt, że często znajduje się ona głęboko pod ziemią, w miejscach, które są niezwykle trudno dostępne, interpretowano jako rys jej pseudoreligijnej funkcji lub jakiś rodzaj roli rytualnej (związanej być może z rytuałami dojrzewania lub polowania) ${ }^{13}$.

Podobnie argument na rzecz istnienia przekonań religijnych u ludzi w okresie górnego paleolitu stanowią też malowidła odkryte w niektórych jaskiniach (malarstwo jaskiniowe subtelnie odzwierciedla przede wszystkim te zwierzęta, z którymi człowiek miał do czynienia, tj. konie, bizony, jelenie, koziorożce, mamuty, nosorożce, lwy, ryby oraz ptaki wodne, rzadziej ludzi, przy czym w szczególny sposób zarysy i odciski ich dłoni, ponadto różne abstrakcyjne kształty). Tę naskalną sztukę trudno jednoznacznie dzisiaj wyjaśnić, dlatego Dunbar podaje kilka hipotez co do jej domniemanych celów. Otóż takie malowidła mogą: 1) obrazować magiczne rytuały, które miałyby przynieść sukces w polowaniu (zwierzęta są czasami ukazane przeszyte strzałami, oszczepami); 2) wiązać się z rytuałem osiągnięcia dojrzałości (lub innym, ponieważ niektóre sylwetki dłoni były małe, czyli typowo dziecięce); 3) przedstawiać podróż po świecie duchów w trakcie szamańskiego transu (ma o tym świadczyć występujący obraz teriantropa, tj. „czarownika” o głowie jelenia); 4) stanowić ikony lub totemy specjalnych związków - stowarzyszeń mężczyzn, których elementem był dany rytuał (np. tańca transowego) ${ }^{14}$.

Brytyjski antropolog dopuszcza też hipotezę, że świadectwa grobów z okresu górnego paleolitu mogą równie jasno wskazywać tylko, że mniej więcej w tym czasie pojawił się pewien dodatkowy element religii już istniejącej wśród ludzi. Była nim owa szczególna wiara w życie pozagrobowe, która implikowała realizację planowanego grzebania zmarłych; decydujące znaczenie miało tutaj przekonanie ludzi, że w zaświatach (jak wcześniej za życia) ciało osoby zmarłej i mienie, które były złożone do grobu, są nieodzowne, stąd starano się je w nim zachować ${ }^{15}$. Autor pisze:

Być może uprzednio ludzie byli po prostu religijni, ale nie wiązali swoich ziemskich ciał z miejscem, gdzie ich duchy egzystują nadal po śmierci. Wszakże mogli oni wierzyć, że gdziekolwiek się udają w chwili śmierci, nie zabierają

Tamże.

Zob. R. Dunbar, Człowiek..., s. 299, 306 i 310-312.

Zob. R. Dunbar, Nowa..., s. 230-231. Dokładny opis przeprowadzonych badań i wyliczeń nie jest tutaj podany. 
z sobą swoich fizycznych ciał. Ponadto nie każda współczesna czy historyczna religia uznaje konserwowanie zwłok za istotne - niektóre (jak Hindusi i wiele grup indoeuropejskich) kremują je, inni (jak Parsowie) wystawiają padlinożercom ${ }^{16}$.

Należy jednak zauważyć, że nie ma tu sprzeczności: otóż „ciało po śmierci” i kremacja nie wykluczają się, tak jak i grzebanie. Hipoteza autora pozwala przypuszczać, że religia mogła wyewoluować przed ponad 30 tysiącami lat, ale jednocześnie osłabia wagę danych archeologicznych, bo w tym przypadku zaplanowany pochówek nie stanowi nieodzownego wyznacznika wiary w życie po śmierci ${ }^{17}$. Trzeba zaznaczyć, że planowany pochówek nie musi wynikać jedynie z wiary w życie pozagrobowe, może on być też przejawem oddania czci osobie zmarłej; jeżeli pochówek nie wiąże się z wiarą w życie pozagrobowe, to nadal stanowi najważniejszy wyznacznik stosunku człowieka do śmierci. Na przykład wiara w Boga Tory hebrajskiej obywała się przez wieki bez wiary w istnienie życia pozagrobowego (a pogrzeby, zwłaszcza sławnych ludzi, jak opisuje Tora, były mocno zrytualizowane).

Dunbar proponuje więc inny sposób (niż wiek pierwszych grobów) do oszacowania momentu pojawienia się religii u ludzi. Ma do tego doprowadzić rozważenie wymagań poznawczych, jakie są niezbędne dla zaistnienia zjawiska religii. W tym celu najpierw należy określić adekwatny stopień intencjonalności dla wiary religijnej, a następnie powiązać go z odpowiadającym mu rozmiarem mózgu człowiekowatych danego czasu dziejowego ludzkości. Trzeba do tego wykorzystać dostępny dziś zbiór skamieniałości ludzkich czaszek sprzed dziesiątek i setek tysięcy lat (ponadto dane dotyczące stopnia intencjonalności małp). Efektem końcowym będzie ustalenie prawdopodobnego czasu wyewoluowania u ludzi takiego poziomu intencjonalności, który umożliwił powstanie religii ${ }^{18}$. Intencjonalność należy tu definiować jako nakierowanie na działanie, będące reakcją systemu nerwowego na czucie: od bólu po rozkosz; temu nakierowaniu zawsze towarzyszą emocje. Dunbar sądzi, że niezbędnym minimum do zaistnienia religii jest drugi stopień intencjonalności - ażeby móc angażować się w praktyki religijne, należy wierzyć $\mathrm{w}$ istnienie innego równoległego świata zasiedlanego przez istoty posiadające intencje, które można modyfikować przez modlitwy.

\footnotetext{
Tamże, s. 230.

Zob. tamże.

Zob. tamże.
} 
Należy jednak zauważyć, że słowa modlitwy „Niech będzie wola Twoja...” nie stanowią jednak modyfikacji intencji, a ponadto modlitwa może być wyrazem czci osoby modlącej się wobec bóstwa. Dunbar nie odróżnia religii od magii otóż treść zaklęcia, a nie modlitwy, może już służyć do modyfikacji danych intencji. Sposób wyrażenia swojej wiary ma tu postać: „Wierzę [1], że istnieją bogowie, którzy zamierzają [2] wpłynąć na moją przyszłość”. Jednak intencjonalność drugiego stopnia nie jest wystarczająca, aby wytworzyć przeświadczenia metafizyczne (religia spełnia pożyteczne cele, jeśli istoty duchowe będą rozumieć pragnienia ludzi), stąd wymagana jest intencjonalność trzeciego rzędu; wtedy możliwy sposób wyrażenia swej wiary ma postać: „Wierzę [1], że istnieją bogowie, których można prosić o zrozumienie [2], czego naprawdę pragnę [3], a ten, kto tak czyni, będzie działać w moim imieniu”. Według Dunbara taka religia nadal nie może stanowić religii w pełnym tego słowa znaczeniu. Co prawda, zapewni osobiste przeżywanie wiary, czy posiadanie własnych przekonań w odniesieniu do wiary, ale nie wystarcza do budowania wspólnotowości religijnej ${ }^{19}$. Dunbar definiuje wspólnotowość religijną jako „występujące na dużą skalę zjawisko złożone z rytuałów oraz społecznego zobowiązania, które w toku praktykowania religii stają się jej centralną częścią"20. Aby powołać wspólnotę religijną, wymagana jest intencjonalność co najmniej czwartego lub nawet piątego stopnia; w takim przypadku możliwy sposób wyrażenia swojej wiary ma tu postać: „Przypuszczam [1], że myślisz [2], że uważam [3], iż istnieją bogowie, którzy zamierzają [4] wpływać na naszą przyszłość, gdyż rozumieją nasze pragnienia [5]”. Dunbar podkreśla, że dopiero taki rodzaj religii może pełnić pożyteczne funkcje w społeczności ludzkiej, i wyłącznie w niej jest możliwy, gdyż czwarty i wyższy stopień intencjonalności przysługuje tylko ludziom ${ }^{21}$. Zatem wraz z uzyskaniem piątego stopnia intencjonalności (przez ludzi anatomicznie współczesnych) nastąpił jakościowy rozwój religijności. Ewentualna religia praludzi (np. neandertalczyka) musiała mieć formę właściwą dla intencjonalności co najwyżej czwartego stopnia; jeśli w ogóle posiadali oni religię, to była bardzo prosta. W kwestii religii Dunbar przypisuje mózgom zachowania religijne od drugiego, czy nawet już od pierwszego poziomu intencjonalności, a jednocześnie twierdzi, że język pojawia się na czwartym i piątym poziomie intencjonalności.

\footnotetext{
19 Zob. tamże, s. 223-224.

20 Tamże, s. 224.

21 Zob. tamże.
} 
Ta ostatnia teza sugeruje sprzeczność, bo czy można wierzyć bez języka, tj. mieć myśli bez języka? Zachowania religijne biorą się ze szczególnych myśli i uczuć, więc nie mogą istnieć bez języka. Religie pierwotne brały się z tych samych myśli i uczuć, co religie współczesne, tyle że znacznie prościej je artykułowały - i to ostatnie zgadzałoby się z wywodem Dunbara o ewolucji religii. Inny zaś sposób interpretacji Dunbara jest taki, że religie oparte na intencjonalności do trzeciego stopnia są religiami indywidualnymi z co najwyżej protojęzykiem, a religie oparte na przynajmniej czwartym stopniu intencjonalności są religiami z rozwiniętym językiem - są religiami właściwymi; tym samym rozróżnia się dwa typy religijności ze względu na stopień rozwoju języka. Religię trzeciego, czwartego oraz piątego stopnia brytyjski uczony określa mianem odpowiednio: religii osobistej, społecznej i społecznościowej22. Mamy tutaj do czynienia z progresją złożoności religii; cechy religii bardziej złożonej zawierają w sobie cechy religii mniej złożonej, występującej wcześniej.

W wyniku przeprowadzonej analizy Dunbar twierdzi, że intencjonalność czwartego stopnia nie powinna się pojawić wcześniej niż około 500 tysięcy lat temu (gdy wszedł na scenę dziejową archaiczny Homo sapiens, pierwszy człowiek współczesny), z kolei intencjonalność piątego rzędu pojawiła się już znacznie później (u kromaniończyka) $)^{23}$. Zatem ustalenie początku religii zależy od tego, jaki stopień intencjonalności stanowić ma konieczny warunek do zaistnienia religii, czwarty lub piąty. Dla Dunbara jasne jest to, że religia nie może funkcjonować bez języka. Zaznacza on, że „społeczny charakter religii opiera się na języku - język jest potrzebny, aby wyjaśnić system religijny i aby przekonać innych do jego przyjęcia, musiał więc być już obecny, zanim został użyty do tworzenia religii”24. Dunbar sądzi, że język jest religii niezbędny szczególnie po to, aby ją sformalizować w społeczności oraz aby osiągnąć konsensus co do natury Boga, w którego się wierzy, i życia po śmierci, o które się zabiega. Przy czym uważa, że sam język nie jest jednak czymś, co pozwala ludziom mieć wiarę religijną ${ }^{25}$. Brytyjski antropo$\log$ konkluduje więc, że religia oparta na czwartym stopniu intencjonalności mogła oto zbiec się w czasie z wykształceniem języka (tj. raczej protojęzyka - np. 300 tysięcy lat temu, gdyż ramy czasowe dla powstania języka szacuje on tu na 500200 tysięcy lat temu). Z kolei religia oparta na piątym stopniu intencjonalności

\footnotetext{
Zob. R. Dunbar, Człowiek..., dz. cyt., s. 306-307.

Zob. R. Dunbar, Nowa..., s. 231-232.

Tamże, s. 232.

Zob. tamże, s. 203.
} 
istnieje co najwyżej 200 tysięcy lat - od czasu, gdy funkcjonował gramatyczny, ustrukturyzowany język, który umożliwiał przekazywanie metafizycznych pojęć niezbędnych dla przekonań religijnych, i gdy już rozwinęła się intencjonalność piątego stopnia ${ }^{26}$. Trzeba jednak podkreślić, że religia powstaje, kiedy pojawia się rozumienie nieuchronności śmierci, a rozumienie to język, może i protojęzyk, jak u neandertalczyka; wówczas człowiek religijnie reaguje, działa (m.in. wytwarza groby) - doktryny religijne są sprawą późniejszą.

\section{Religia szamanistyczna i jej społeczna funkcja}

Dunbar wskazuje, że obecnie ludzie są skłonni myśleć o religii w kategoriach wielkich i międzynarodowo zorganizowanych obrządków (np. chrześcijaństwo, judaizm, islam, hinduizm czy buddyzm), jak i potężnych nurtów religijnych przeszłości (m.in. kult słońca Azteków i Inków, politeizm tradycyjnej greckiej i rzymskiej religii państwowej, zaratusztrianizm starożytnej Persji), a każda $\mathrm{z}$ tych religii cechuje się zaawansowaną doktryną, wysoce zorganizowaną formą kultu, jak też międzynarodowymi strukturami formalnymi. Jednak nie zawsze tak było. Według brytyjskiego naukowca religia charakteryzuje się intymnością, wynikającą nie z politycznych hierarchii, lecz z bliskości osobistych relacji między ludźmi skupiającymi się w małych grupach. Jest wielce prawdopodobne, że w takim kształcie narodziła się religia wśród naszych przodków (pośród wędrownych grup łowiecko-zbierackich) ${ }^{27}$. Dunbar daje przykład współcześnie żyjącego plemienia. Uważa bowiem, że są podstawy, by sądzić, że jego religia przypomina pierwotną wiarę religijną. Pisze on:

Wśród Buszmenów !Kung z pustyni Kalahari w Afryce Południowej religia wyraża się w systemach przekonań odnoszących się do ukrytego świata duchowego i w rytuałach tańców transowych, które dają ludziom dostęp do tego świata. Nie ma tam księży, chociaż niektóre osoby można uznać za szczególnie biegłe w komunikacji ze światem duchów. [...] Co najmniej w niektórych

26 Zob. tamże, s. 232 i 238. Na temat problemu pojawienia się języka u ludzi i związanych z nim kwestiach zob. B. Wolniewicz, O związku myślenia z językiem (Tezy), „Przegląd Filozoficzny Nowa Seria” 2018, nr 3(107).

27 Zob. R. Dunbar, Nowa..., dz. cyt., s. 234. 
przypadkach te plemienne religie - jak się wydaje - nawet nie mają koncepcji życia pozagrobowego, które czeka nas po śmierci ${ }^{28}$.

Należy zauważyć, że jest to argument na to, iż religia może istnieć bez doktryny: w tym przypadku ry tuał religijny jest, a doktryny nie ma, czy też jest tylko szczątkowa.

Dunbar podkreśla, że religia szamanistyczna (jako początkowe stadium w rozwoju wszystkich religii) cechuje się prostotą, której dane cechy można jeszcze współcześnie zaobserwować:

W małych, tradycyjnych społecznościach religia nie jest ćwiczeniem intelektualnym i nie występuje w niej złożona teologia. Jest czymś, czego doświadcza się bezpośrednio, często przy udziale szamana i stanów ekstatycznych $[\ldots]^{29}$.

Praktyki szamańskie wykorzystują muzykę i taniec, które, czasami w połączeniu z substancjami halucynogennymi, doprowadzają wiernych do stanu transowego - częściową lub pełną utratą świadomości. W trakcie transu uzyskuje się dostęp do świata duchów, następnie ma miejsce podróż przez ten świat (zazwyczaj przy obecności przewodnika ze świata przodków lub pomocnych istot duchowych). Podróż do świata duchów zachodzi tylko w umyśle konkretnej osoby, lecz jest tak intensywna, że wydaje się rzeczywista ${ }^{30}$. Ponadto cechą religii szamanistycznej (jak też każdej innej) jest opowiadanie historii. Stanowi ono często opowieść o pradawnych przodkach i istotach bytujących w świecie duchów, zwykle istotną rolę spełnia tutaj historia hagiograficzna. Stąd też w szamanizmie wskazana jest pewna umiejętność opowiedzenia innym o swojej podróży duchowej (jak również uzyskanie wspólnego porozumienia odnośnie do tego doświadczenia). Jednak język nie pełni tutaj pierwszoplanowej roli; a zatem religia taka nie posiada cech dopracowania teologicznego i dużego wyrafinowania na płaszczyźnie poznawczej (m.in. nie ma w niej bogów jako takich, a większość spotykanych w świecie duchowym istot jest znajoma) ${ }^{31}$. Brytyjski uczony twierdzi, że religie szamanistyczne mają kilka wspólnych motywów. Są to: 1) wejście do świata duchów przez otwór (czy też tunel), za którym po eksplozji światła ukazuje się rozświetlony świat; 2) zgoda co do tego, że podróż do świata duchów jest bardzo

\footnotetext{
Tamże, s. 234-235.

R. Dunbar, Człowiek..., dz. cyt., s. 297.

Zob. tamże.

Zob. tamże, s. 297-298.
} 
niebezpieczna, i dlatego wymagająca obecności przyjaznego przewodnika w postaci przodka lub zwierzęcia totemicznego; 3) lęk przed nieodnalezieniem otworu wyjściowego, a zatem przed pozostaniem po drugiej stronie (lęk ten można też interpretować w kategoriach strachu przed groźbą śmierci na skutek zbyt wyczerpującego tańca transowego) ${ }^{32}$.

Dunbar przytacza argumenty archeologa z RPA (Davida Lewisa-Williamsa), który uważa, że szamanizm stanowi oryginalną formę religii ludów prehistorycznych. Otóż pierwszym argumentem jest tutaj, istniejąca we wszystkich społecznościach ludzkich, powszechność zdolności wchodzenia w stany transowe. Ich stałą podstawą są muzyka i taniec, czasami specjalne praktyki medytacyjne, od czasu do czasu też pewne środki psychoaktywne (jak m.in. meskalina, obecnie chętnie stosowana przez Meksykanów). Drugim argumentem jest rzekome uchwycenie stanów transowych w sztuce naskalnej. Osobliwe wzory na malowidłach ludzi prehistorycznych oraz współczesnych łowców-zbieraczy (w postaci kropek, krat, zygzaków oraz krętych linii) są zbieżne. Mają one wykazywać podobieństwo do pewnych elementów występujących w doświadczeniach ludzi, którzy zażywają środki halucynogenne w ramach eksperymentu - badane osoby opisywały umysł przytłoczony doznaniem (m.in. przez intensywność i blask lśniących, migających punktów lub linii), mogą być u nich diagnozowane odczucia przebywania poza ciałem, zamiany w dane zwierzę lub mityczną postać, zjednoczenia $\mathrm{z}$ bóstwem ${ }^{33}$.

Lewis-Williams omawia i inny wymowny przykład sztuki naskalnej u współczesnych Buszmenów w Afryce Południowej. Otóż wiele ich malowideł prezentuje grupę ludzi, ustawioną w linii, zazwyczaj dzierżących w dłoniach kije. Początkowo sądzono, że te malowidła obrazują mężczyzn w trakcie polowania lub też idących do walki na dzidy, w rzeczywistości mogą zaś one mówić o zupełnie innej rzeczy (mianowicie o tańcach transowych) ${ }^{34}$. Jak pisze Dunbar:

Jedną z przyczyn takiej interpretacji jest to, że niejednokrotnie występują tam kobiety [...], w tle lub nawet wmieszane w grupę mężczyzn. Drugim powodem jest obecność antropomorfów (ludzkich postaci ze zwierzęcymi głowami).

\footnotetext{
Zob. tamże, s. 298.

Zob. R. Dunbar, Nowa..., dz. cyt., s. 235-236.

Zob. tamże, s. 236.
} 
Wydaje się ona mało istotna dla magii łowieckiej, nie mówiąc już o bitwach, ale stanowi - jak się zdaje - częstą właściwość stanów transowych ${ }^{35}$.

Ponadto widniejące u postaci męskich kije można interpretować jako krew tryskającą z nosa, gdyż zazwyczaj wśród buszmeńskich tancerzy w kulminacyjnym momencie ich tańca, kiedy wchodzą w stan transu, mają miejsce krwotoki $\mathrm{z}$ nosa $^{36}$.

Według Dunbara taniec transowy (w efekcie którego tworzono pewną wizję „świata poza tym światem”) mógł zostać zapoczątkowany przez przypadkowe doświadczenia zaledwie kilku osób, które były zaangażowane w działania formujące społeczność za pomocą muzyki i tańca. Rola muzyki i tańca w kształtowaniu społeczności wiązała się najpierw z czysto chemicznym efektem (generowanym przez skoki poziomu endorfin, wytwarzanych w trakcie stanów transowych), który przyczynił się do wiązania dużych i rozproszonych grup myśliwskich. Intelektualne oraz praktyczne konsekwencje religii (tzn. i wszystkie pozytywne funkcje religii) uwidoczniły się dopiero znacznie później. Z drugiej strony autor sugeruje, że zaczątki religii pierwotnej zawierają też w sobie podstawę dla rozwoju religii zinstytucjonalizowanych. Otóż szaman staje się świętym mężczyzną (lub kobietą), posiadającym magiczne moce, mogącym kontrolować świat ziemski i duchowy, czyniącym cuda, podnoszącym komfort życia ludzi, pomagającym zmarłym pokonać drogę do innego świata po śmierci. Jest osobą z ogromną charyzmą, swego rodzaju ekspertem w obcej większości ludzi dziedzinie; stąd jest dość blisko do kapłanów, systemu religijnej hierarchii i pełniących analogiczne funkcje instytucji ${ }^{37}$.

Należy zaznaczyć, że Dunbar ponownie błędnie utożsamia tu cechy religii i magii: w religii uwidacznia się kwestia czci, a w magii kwestia manipulacji światem. Magia jest skomplikowaną umiejętnością. Składają się na nią i wzajemnie krzyżują się w niej różnorodne pojęcia, wyobrażenia i techniki (czynności). Niemniej jednak można wyróżnić trzy elementy stanowiące wspólny zrąb każdej magii: 1) przedmioty mające moc magiczną, które są wykorzystywane w obrzędzie magicznym, 2) czynności zmierzające do pozyskania danego celu (są to, w przeciwieństwie do czynności realnych, tzw. czynności iluzoryczne), 3) formuły i zaklęcia słowne (ich celem jest spotęgowanie udziału środków i czyn-

\footnotetext{
Tamże.

Zob. tamże.

Zob. tamże, s. 237.
} 
ności w obrzędzie magicznym, wyzwolenie ukrytej siły i mocy, ukierunkowanie celu działania, który chce się osiągnąć, jak też skoncentrowanie uwagi i wysiłku psychofizycznego $)^{38}$. Magia spełnia trzy funkcje: praktyczne, poznawcze i psychologiczne. Stanowią one o różnicy między zjawiskami religii a magii. Otóż w magii każdy cel ma charakter praktyczny, utylitarny. Magia występuje tylko w ramach praktycznej działalności człowieka (np. łowieckiej, produkcyjnej; ogólnie są to praktyczne oddziaływania ludzi na przyrodę). Natomiast przekonania religijne, uczucia religijne, rytuały religijne, kulty religijne czy nawet gesty religijne mogą istnieć same dla siebie, tym samym mogą być bezinteresowne. Funkcja poznawcza magii przejawia się w tym, że stanowi próbę wyjaśniania, czy też wykrywania, mechanizmów zachodzących w przyrodzie. Przez to człowiek odczuwa prawa związku - przyczynowości i m.in. ścisłej zależności swego istnienia od przyrody. Religie nie spełniają w istocie takiej funkcji (nawet jeżeli są religie, które starają się to robić). Funkcja psychologiczna magii sprowadza się do pozbycia się lęku, bezradności i niepewności, a także rozładowania napięcia nerwowego u człowieka. Religie, chociaż mogą, nie muszą tego czynićs ${ }^{3}$.

Dunbar sądzi, że religie szamanistyczne miały ogromne znaczenie dla przetrwania człowieka w epoce prehistorycznej. Otóż pełnione przez nie funkcje były nieodzowne w ludzkich populacjach, gdyż wedle standardów miary grup małp naczelnych ludzkie społeczności już wówczas były bardzo duże ${ }^{40}$. Religie szamanistyczne wyewoluowały jako mechanizm zwiększenia spójności grupy i zdolności do wzajemnego poświęcenia w danych grupach, nawet jeśli ocenianych dziś jako mało licznych. Główne znaczenie dla utrzymania równowagi społecznej w grupie ma tu taniec transowy. Wśród współczesnych Buszmenów z południowej Afryki zwykle organizuje się tańce transowe wtedy, gdy relacje w ich wspólnocie rozluźniają się wskutek starć pomiędzy jej członkami. Taki taniec pozwala przywrócić równowagę społeczną, poniekąd zmyć toksyczne ślady po niesprawiedliwościach i zniewagach, które zatruły życie społeczne. Wspólny trans doprowadza do wyjściowego stanu relacji międzyludzkich, tym samym do ponownego funkcjonowania owej społeczności jako sieci wzajemnie pomagających sobie jednostek. Taniec transowy jest zwoływany dopiero po kolejnych tygodniach lub miesiącach, gdy nieporozumienia i konflikty znów się skumulują ${ }^{41}$.

\footnotetext{
Zob. H. Swienko, Religia i religie, Warszawa 1981, s. 143.

Zob. tamże, s. 185-189.

Zob. R. Dunbar, Człowiek..., s. 313.

Zob. tamże s. 298 i 300.
} 
Ponadto bardziej złożone współczesne religie (wraz z analogicznymi, choć innymi, rytuałami) dowodzą, że przyczyniają się do utrzymywania spójności dużych społeczności. Dunbar pisze, że obecnie nadal „uczestnictwo w grupie religijnej zwiększa poczucie przynależności do społeczności i zwykle sprawia, że ludzie stają się względem siebie bardziej hojni (czasem zaś, choć oczywiście nie zawsze, również względem obcych). Istotne jest jednak nie to, czy religia sprawia, że ludzie stają się bardziej "prospołeczni» (co może być tylko korzystnym skutkiem ubocznym), ale czy są oni bardziej oddani członkom własnej społeczności”"22.

Brytyjski uczony podaje hipotetyczną przyczynę dobroczynnego działania tańca transowego. Otóż prawdopodobnie taniec transowy (o ile nie stan transowy sam w sobie) wiąże się z wydzielaniem potężnej dawki endorfin, dzięki którym - za sprawą swojej pradawnej zdolności do wzmacniania więzi - jest możliwe odtworzenie dobrych międzyludzkich relacji. Nie bierze on jednak pod uwagę, że jest to efekt działań religii, a nie przyczyna. Endorfiny mają również korzystny wpływ na zdrowie fizyczne i psychiczne, stąd poza podnoszeniem spójności społecznej grupy taniec transowy ma pozytywny wpływ na całościowy stan zdrowia człowieka. Dunbar pisze też, że w kontekście prozdrowotnej funkcji tańca transowego (jako rytuału) powstaje nieporozumienie wokół tego, czy jest tu istotna sama religia (rozumiana dziś często jako wiara w Boga), czy raczej aktywny udział w rytuałach religijnych. Jego zdaniem dużo większe znaczenie ma jednak drugi czynnik ${ }^{43}$. Trzeba zaznaczyć, że istotą religii nie są wydzielane endorfiny, bo gdyby tak było, to wówczas efekty religii można by zastąpić jakimś substytutem, np. biegami długodystansowymi, podczas których endorfiny także wydzielają się w dużych ilościach. Konsekwencją silnego spajania grupy przez taniec transowy jest wyraziste oddzielanie jej od innych grup w otoczeniu (czego nieuniknionym skutkiem są międzyplemienne antagonizmy). Można sądzić, że jest to sytuacja niekorzystna pod względem przetrwania, ale brytyjski antropolog przytacza wyniki badań amerykańskich biologów (Cory Fincher i Randy Thornhill), uwidaczniające płynący z tego pożytek dla wrogich wobec siebie grup. Okazuje się, że kluczowym sposobem na obniżenie ryzyka zachorowalności w warunkach wysokiego narażenia na patogeny jest unikanie mieszania się grup (eliminacja groźby zakażenia $\mathrm{w}$ trakcie współżycia osobników $\mathrm{z}$ różnych grup). Tak więc rozsądne wydaje się takie postępowanie, które pozwala trzymać

42 Tamże, s. 302.

43 Zob. tamże, s. 300. 
się tylko własnej grupy i własnych chorób, które są mniej groźne ze względu na to, że dana grupa miała sporo czasu na uzyskanie odporności na nie ${ }^{44}$. Należy zauważyć, że jest wątpliwe, aby religia powstała głównie dla celów zdrowotnych czy sanitarnych; do ich realizacji można było przecież zastosować inne, skuteczniejsze środki.

\section{Funkcje religii}

Według Dunbara nawet pobieżne spojrzenie na rozliczne religie współczesne pozwala wysnuć wniosek, że religia pełni w ludzkim życiu różne - bardzo istotne - funkcje, są to: 1) nadawanie światu spójności poznawczej (wytworzony na gruncie wiary religijnej metafizyczny model świata tłumaczy, dlaczego świat jest taki, a nie inny, i umożliwia jego zrozumienie); 2) zapewnianie poczucia większej kontroli nad ludzkim życiem (przez modlitwę i inne rytuały) - te dwie funkcje stanowią próbę ułatwienia funkcjonowania człowiekowi w świecie, który nie jest tak sprawiedliwy (tzn. tak wspaniały lub idealny), jakby sobie on życzył; 3) ustanawianie norm społecznych (tworzenie systemu etycznego, postawy moralnej); 4) umożliwienie mniejszości sprawowania kontroli nad społeczeństwem - te dwie funkcje wiążą się z szeroko rozumianą kontrolą społeczną ${ }^{45}$.

Autor ten wskazuje, że nadawanie światu spójności poznawczej przez religię (tj. religia jako punkt odniesienia dla zrozumienia rzeczywistości) nie ma na celu udzielania ludziom jak najdokładniejszych odpowiedzi na różne pytania; po pierwsze, nie jest w stanie wprost wyjaśnić (jak stara się to robić nauka) ukrytych mechanizmów funkcjonowania świata, a po drugie, nie to jest najważniejsze wiedza religijna o świecie (np. zawarta w Biblii czy mitach aborygeńskich) ma za zadanie jedynie wprowadzać pewien porządek, który sprawia, że człowiek będzie działać efektywniej w wielce skomplikowanym świecie ${ }^{46}$. Niestety Dunbar nie pisze, o jaki porządek tu chodzi; na pewno istotna jest kwestia poradzenia sobie - wprowadzenia „porządku” w odniesieniu do faktu śmierci najbliższych osób. Istotą tej funkcji jest prostota modelu poznawczego świata, ponieważ ludzki umysł nie może być przeładowany wszystkimi prawidłowościami zaobserwowa-

\footnotetext{
44 Zob. tamże, s. 300-301.

45 Zob. R. Dunbar, Nowa..., dz. cyt., s. 204.

46 Zob. tamże, s. 205 i 207.
} 
nymi w świecie. Posiadanie modelu tłumaczącego pewną część z nich znacznie zmniejsza obciążenie poznawcze człowieka. Lepiej pamiętać mniej, bo więcej da się wywnioskować $\mathrm{z}$ kilku podstawowych reguł. Ponadto nieważne tu jest, jak dokładnie dany model przystaje do rzeczywistości - musi tylko tłumaczyć działanie świata przez łączenie z sobą pozornie niezwiązanych elementów w logiczny i spójny sposób. Trzeba przy tym podkreślić, że jeżeli tak, to wówczas już nie można twierdzić, iż jedną z funkcji religii jest funkcja poznawcza. Im model będzie prostszy do zrozumienia (a więc mniej skomplikowany), tym lepiej zadziała. Niewiele człowiekowi po wytłumaczeniu jakiegoś zjawiska tak skomplikowanego i trudnego do potwierdzenia, gdy $\mathrm{z}$ tego powodu zmarnuje czas, zamiast poszukiwać pożywienia czy partnera. Ma tutaj zastosowanie tak zwane prawo malejących korzyści, które głosi, że zawsze istnieje taki punkt, poza którym nie warto (w kontekście potrzeby przetrwania człowieka) już bardziej zgłębiać i wyjaśniać rzeczywistości ${ }^{47}$.

Dunbar zaznacza, że z uwagi na to, że ludzki umysł jest niezwykle wrażliwy, ludzie nie mogą przejść do porządku dziennego nad naporem przeciwności losu, szczególnie nad tak traumatycznym wydarzeniem, jakim jest śmierć najbliższych osób. Religia jest w takich przypadkach punktem oparcia, pozwala przetrzymać najtrudniejszy czas, aby nie pogrążyć się w całkowitej rozpaczy (i w efekcie porzucić chęć do życia). Modlitwa i system metafizyczny (jako charakterystyczne składniki religii) dodają ludziom siły, dzięki której w bolesnej sytuacji nie załamią się i nie zginą ${ }^{48}$. Autor pisze:

Ludzie religijni [...] wydają się szczęśliwsi niż niewierzący. [...] istnieją dobre empiryczne dowody potwierdzające to. Ludzie wierzący rzadziej zapadają na choroby fizyczne i psychiczne, ponadto jeśli już zachorują, szybciej odzyskują siły po chorobie lub inwazyjnych metodach leczenia (takich jak operacja lub chemioterapia). Jedną z przyczyn tego stanu rzeczy musi być poczucie większej kontroli nad sytuacją - Bóg będzie miał ich w opiece, cokolwiek się stanie. [...] Nie ma przypadku w tym, że prawie każda religia obiecuje swoim członkom, że oni - i tylko oni - są Bożymi wybrańcami, którzy niezależnie od wszystkiego dostąpią zbawienia, oraz że Bóg [...] pomoże im w codziennych

47 Zob. tamże, s. 206-207.

48 Zob. tamże, s. 207-208. Na temat znaczenia śmierci dla istnienia religii zob. B. Wolniewicz, O istocie religii, w: tegoż, Filozofia i wartości, Warszawa 1993. 
zmaganiach, jeśli tylko wypełnione zostaną rytuały i odmówione modlitwy.

Jest to niewątpliwie źródłem bezpieczeństwa w trudnych czasach ${ }^{49}$.

Dunbar nie bierze pod uwagę faktu, że żadna z wielkich religii monoteistycznych nie obiecuje zbawienia (mają go dostąpić postępujący „,w sposób prawy”, definiowany w ramach danej religii). Ponadto bardziej niż religia mogą generować pożądane skutki czynności magiczne. Należy zauważyć, że kategoria zbawienia,

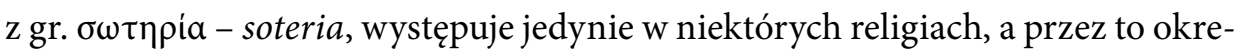
ślanych właśnie mianem religii soteriologicznych; Dunbar ma tu pewnie na myśli nieśmiertelność (chociaż, w zależności od religii, różnie rozumie się soterię; nie chodzi w niej na pewno o nieśmiertelność jako taką, ale o jej „jakość”).

Brytyjski antropolog twierdzi, że w wypadku religii monoteistycznych (podobnie jak w religii szamanistycznej) decydującą rolę pełni zwiększona produkcja endorfin w mózgu. Dzieje się to zaś za sprawą praktyk, które są w wielu religiach zalecane ich wyznawcom i następnie przez nich stosowane. Religie posiadają odmienne tradycje i procedury postępowania (kładą inny nacisk na kwestię czynności uznanych za właściwe dla danego zwyczaju religijnego), ale mimo to jedno je łączy. Otóż w większości religii są widoczne pośród wyznawców takie zachowania, które wiążą się z zadawaniem fizycznego bólu i/lub wywoływaniem lekkiego stresu. Zaliczamy do nich między innymi: post, taniec i inne miarowe ruchy (np. rytmiczne kołysanie się ortodoksyjnych żydów podczas modlitwy pod Ścianą Płaczu w Jerozolimie, modlitwa katolików połączona z monotonnym liczeniem paciorków różańca), biczowanie się lub spełnianie innych czynności powodujących ból (jak np. pokonywanie drogi krzyżowej na kolanach lub długie godziny spędzane na zamkniętych nabożeństwach w niektórych religiach chrześcijańskich, natomiast w tradycjach jogicznych, np. buddyzmie, trudne do zniesienia długotrwałe okresy bezruchu w pozycji siedzącej), w wielu plemiennych społecznościach bolesne i budzące strach obrzędy inicjacyjne, wspólne wykonywanie pieśni (szczególnie monotonnych, ale też żarliwych hymnów), emocjonalna huśtawka wiernych wywołana przez najbardziej charyzmatycznych kaznodziejów ${ }^{50}$.

49 Tamże, s. 208.

50 Zob. tamże, s. 209. 
Dunbar zaznacza, że wszystkie powyższe praktyki (jak też wiele innych) wzbudzają w ludzkim ciele lekki, stały stres, a taki rodzaj ciągłego stresu o niskim natężeniu jest skuteczny właśnie w stymulowaniu produkcji endorfin ${ }^{51}$.

Należy zauważyć, że jest to wątpliwa teza, gdyż dla przykładu rozwiązanie zadania matematycznego też może spowodować wydzielanie się endorfin - czy to znaczy, że matematyka jest stworzona dla endorfin? Nie, endorfiny są raczej pewnym efektem ubocznym realizacji różnych celów.

Dunbar przytacza opis mechanizmu działania systemu endorfinowego w przypadku długodystansowych biegaczy. Otóż dzięki niemu ma u nich miejsce radzenie sobie $\mathrm{z}$ dyskomfortem podczas biegu (tj. bólem i wysiłkiem). Prawdopodobnie jest on też $\mathrm{w}$ jakimś stopniu odpowiedzialny za powrót sił (i w tym przyjemnego poczucia błogostanu), co powoduje, że biegacze mają motywację do aplikowania sobie systematycznego wysiłku w tej postaci. Efektem tego jest swego rodzaju uzależnienie się od biegania (tj. w razie jego braku uwidaczniają się w ludzkim organizmie wszystkie typowe objawy łagodnej formy głodu narkotycznego - spięcie i drażliwość, a zanikające w momencie ponownego dostarczenia endorfin $)^{52}$. Stąd autor wyciąga następujący wniosek:

Zdaje się więc, że praktyki religijne są skonstruowane w celu zaoferowania nam opioidowego zastrzyku, który sprawia, że czujemy się znacznie bardziej zdolni do umiejętnego radzenia sobie z kaprysami świata, a być może, co równie istotne, o wiele mocniej pojednani z naszymi bliźnimi. Lecz może być też tak, że produkcja endorfin związana z tymi praktykami stymuluje układ odpornościowy do zwiększonej aktywności, a więc bezpośrednio chroni organizm przed chorobą i urazami ${ }^{53}$.

Dunbar wskazuje, że czynności związane z zadawaniem bólu i stresu czasami nawet stawały się centralnym założeniem poszczególnych wspólnot religijnych. Przykładem są tutaj tak zwani flagelanci (włoski ruch pokutniczy zapoczątkowany w XIII w., który miał wiele późniejszych naśladowców, np. w prawosławnej Rosji działał analogiczny ruch od XIV w. aż do co najmniej końca XIX w., a na Bliskim Wschodzie islamska wspólnota derwiszów oraz szyitów). I chociaż mieli oni głównie na celu odpokutowanie za grzechy przez samobiczowanie, to

\footnotetext{
51 Zob. tamże, s. 209-210.

52 Zob. tamże, s. 210.

53 Tamże.
} 
jednak istotne wydaje się tu też dążenie do osiągnięcia stanu religijnej ekstazy (dzięki podnoszeniu poziomu endorfin w mózgu). Znamienne jest, że nie przetrwały długo skrajne odłamy takich wspólnot, które nie ograniczały się jedynie do biczowania (m.in. stosowały kastrację). Widocznie przekroczono punkt, po którym spadła efektywność w wywieraniu dobroczynnego wpływu endorfin na organizm ${ }^{54}$.

Ponadto brytyjski antropolog przytacza wyniki eksperymentalnego odkrycia dwóch badaczy (są to neuronaukowiec Andrew Newberg i antropolog Eugene d'Aquili), które mówią, że u osób osiągających intensywny stan religijnej ekstazy wykazano specyficzne wzorce aktywacji mózgu. W ich przypadku obraz mózgu odznaczał się istotnym obniżeniem aktywności obszaru tylnego płata ciemieniowego w lewej półkuli, który odpowiada za nasze poczucie własnego ciała w przestrzeni. Stąd badacze argumentują, że starannie dobrane praktyki umysłowe (w tym techniki medytacyjne) osób religijnych pozwalają znacząco zmniejszyć zaangażowanie dróg neuronalnych tej części mózgu, jak i nawet całkowicie je wyciszyć. Skutkiem tego miałyby być doznania mistyczne jak: eksplozja ekstatycznej emancypacji wraz z ogarniającym umysł blaskiem oślepiającego światła, poczucie zjednoczenia z nieskończonością bytu (albo Bogiem), poczucie wyzbycia się ciała i unoszenia się nad nim umysłu (lub duszy), poczucie przebywania w ciszy. Dalej zaznacza Dunbar, że wyjęcie grupy neuronów spod kontroli pozostałej części mózgu prowadzi ostatecznie do powstania obiegu (neuronalnej pętli) wokół wyłączonej części mózgu z wykorzystaniem podwzgórza (tzn. głównego miejsca, $z$ którego endorfiny są uwalniane do reszty mózgu). Dodaje on też, że wyciszony obszar płata ciemieniowego mózgu został stąd nazwany „ośrodkiem boskim”. Autor wskazuje, że uzyskane w ten sposób doznania są tożsame z doznaniami pojawiającymi się w sytuacji doświadczania stanu z pogranicza śmierci (rezultat niedotlenienia mózgu). Zatem praktykujący ludzie religijni odkryli sposób wolicjonalnego wywoływania stanu niedotlenienia mózgu ${ }^{55}$.

Poza psychofarmakologicznymi korzyściami płynącymi z religii bardzo istotne są także pozytywne efekty wynikające z samego zaangażowania się ludzi w ruchy religijne. Otóż przynależność do zorganizowanych grup religijnych oznacza dla człowieka bycie członkiem wspólnoty, natomiast wspólnotowość może

\footnotetext{
54 Zob. tamże, s. 211-212.

55 Zob. tamże, s. 212-214.
} 
przejawiać się we wzajemnym wspieraniu się we wzmożony sposób ${ }^{56}$. Dunbar przytacza wyniki badań, które mówią, że zdolność do opierania się chorobom i radzenia sobie $\mathrm{z}$ traumatycznymi przeżyciami jest wśród ludzi dodatnio skorelowana z zakresem ich społecznych kontaktów. Jednym z nich jest wynik badania dotyczącego wpływu wielkości rodziny na stan zdrowia jej członków (przeciętnie dzieci z większych rodzin cierpią na mniej chorób oraz rzadziej umierają niż dzieci z mniejszych rodzin; nie zawsze tak musi być, jednak statystycznie rzecz biorąc, większość ludzi łatwiej sobie radzi z różnymi przeciwnościami w dużych rodzinach $)^{57}$ :

W rodzinie i towarzyszącym jej poczuciu przynależności kryje się coś, co stanowi wsparcie dla ducha, pozwala nam na ogół czuć się bardziej zdolnymi do wzięcia świata na swoje barki i w istocie sprawia, że udaje się to lepiej. Faktycznie istnieją pewne dane świadczące, że silne wsparcie krewnych ma pozytywny wpływ na nasz system odpornościowy $[\ldots]^{58}$.

Dunbar jest przekonany, że religia odgrywa podobną rolę w zapewnieniu ludziom poczucia wspólnoty i przynależności jak rodzina. Można to potwierdzić wymownym nazewnictwem, które jest stosowane w chrześcijańskiej tradycji. Otóż Kościół jest tu określany mianem „rodziny” (ponadto Bóg jest rozumiany jako Ojciec, a Maryja jako Matka Boga), tytuł „ojciec” stanowi grzecznościowy zwrot względem kapłanów, a terminy „brat” oraz „siostra” są kierowane w stronę członków społeczności chrześcijańskiej. Budowanie więzi pararodzinnych w ramach wspólnoty religijnej sugeruje, że religijność wyewoluowała, aby ułatwić psychiczne wiązanie rozbudowanych grup, w których ludzie spędzili większość swego ewolucyjnego czasu ${ }^{59}$. Należy zauważyć, że religia raczej powstała przypadkiem, wraz z językiem, jako „sposób” na świadomość śmiertelności, a dopiero później okazało się, że religijność jest również prospołeczna. Autor pisze:

Podzielanie punktu widzenia i - jakkolwiek może się to wydawać arbitralne wspólnego zestawu zasad żywieniowych, rytuałów oraz zakazów może pełnić równie ważną, symboliczną funkcję spajania grupy jak dzielenie tego samego dialektu. Rzeczywiście, im bardziej wymagające są dane praktyki, tym lepszą

\footnotetext{
Zob. tamże, s. 214.

Zob. tamże, s. 215.

Tamże, s. 216-217.

Zob. tamże, s. 217.
} 
oznakę zaangażowania na rzecz wspólnego celu stanowią. To poczucie wspólnoty staje się szczególnie wyraziste, gdy koncentruje się wokół jakiejś wybitnie charyzmatycznej postaci ${ }^{60}$.

Zdaniem Dunbara religia spełniła kluczową funkcję we wczesnej ewolucji ludzi (tj. głównie w tej ich historii, gdy gromadzili się w małych liczebnie środowiskach). Otóż w małych grupach religia daje bardzo silne podstawy do egzekwowania danych norm, niezależnie od tego, czym one są. To prawdopodobnie wówczas religia pełniła funkcję ograniczania jednostkowych interesów, które mogłyby obniżać skuteczność działania w skoordynowanej grupie. Jeżeli grupa ma efektywnie wykonywać swoje zadania (do których w szczególności należy zapewnienie jej poszczególnym członkom możliwości przetrwania i reprodukcji), to priorytetowa staje się potrzeba kontroli destrukcyjnego wpływu tych, którzy łamią wspólny trend w działaniu całej grupy. Ma się tu na myśli pewnych indywidualistów (nie dotyczy to charyzmatycznych przywódców), „wolnych strzelców”, którzy nie chcą współpracować ${ }^{61}$. Autor pisze:

Presja ta [...] odpowiada za wyewoluowanie umysłu predysponowanego do utożsamiania się ze zbiorowym punktem widzenia, zwłaszcza gdy jest on wyrażony w kategoriach religijnych oraz silnie wzmocniony bogatym w emocje koktajlem muzyki, tańca i rytuału. Religia, krótko mówiąc, powstała prawdopodobnie dlatego, że jest pożytecznym mechanizmem służącym spajaniu grup społecznych i nakłanianiu ich członków do wspólnej pracy w imię wspólnego interesu. Przede wszystkim właśnie to nieprzerwanie kierowało ewolucją religijnego umysłu ${ }^{62}$.

Trzeba zaznaczyć, że rewolucją kulturową bardziej kierują bezwiednie zmieniające się warunki życia ludzi niż namysł nad interesem.

\footnotetext{
Tamże.

Zob. tamże, s. 222.

Tamże, s. 222-223.
} 


\section{Religie szamanistyczne a religie hiperdoktrynalne ${ }^{63}$}

Rewolucję neolityczną (która nastąpiła w przedziale czasowym od ok. 12 tysięcy do 8 tysięcy lat temu na Bliskim Wschodzie) cechowały dwie ważne innowacje: porzucenie życia zbieracko-łowieckiego (nomadyzmu) na rzecz życia osiadłego oraz wynalezienie rolnictwa. Dunbar sądzi, że istnieje jeszcze trzecia charakterystyczna cecha rewolucji neolitycznej: zamiana religii szamanistycznej na religię hiperdoktrynalną. A co więcej, uważa on, że rewolucja neolityczna była przede wszystkim rewolucją religijną (dwie wymienione powyżej cechy miały mieć mniejsze znaczenie, a w najwyższym stopniu nastąpiła ona w czasie od ok. 8 tysięcy do 6 tysięcy lat temu, czyli w końcowej fazie neolitu preceramicznego B ${ }^{64}$. Trzeba zaznaczyć, że jeżeli rewolucja religijna nastąpiła dopiero w końcowej fazie neolitu, to jest ona skutkiem zmiany sposobu życia; doktryny religijne wówczas uległy rozbudowaniu.

Brytyjski antropolog twierdzi, że wszystkie istniejące dziś religie świata można zakwalifikować fundamentalnie w ramach dwóch typów religii, a mianowicie religii szamanistycznych i religii hiperdoktrynalnych. Ewidentna różnica między nimi polega na tym, że religie szamanistyczne są bardziej swobodne, opierają się na osobistym doświadczeniu danej osoby. Religie hiperdoktrynalne są silniej zorganizowane, wiążą się z uświęconymi przestrzeniami (świątyniami i kościołami), hierarchiami kapłanów, teologiami, bogami (w tym pojęciem Boga Najwyższego rządzącego ludzkim życiem) i sformalizowanymi rytuałami (które mają na celu obłaskawienie bogów i sprowadzenie pomyślności). Tym samym uwidacznia się ogólna różnica w sposobie uprawiania religii. Dunbar przytacza pogląd, że powstanie trwałych osiedli może wyznaczać moment, w którym nastąpiło przejście między tymi dwoma typami religii (wszakże teraz społeczności nomadyczne i półnomadyczne ludy łowiecko-zbierackie mają religie szamanistyczne, a osiadłe społeczeństwa praktykują religie typu hiperdoktrynalnego) ${ }^{65}$. Według niego najlepiej można by wyjaśnić to przejście konsekwencją faktu, że łatwiej jest po prostu wznieść budynki dla celów rytualnych, gdy się prowadzi tryb osiadły. Lecz zauważa przy tym, że nie ma żadnego oczywistego powodu, dla któ-

63 Dunbar używa jedynie wyrażenia „religia doktrynalna”, a nie „hiperdoktrynalna”. Jednak to rozróżnienie na religie hiperdoktrynalne (jak katolicyzm) i doktrynalne (jak szamanizm) jest tu uzasadnione, bo pomaga ukazać różnice.

64 Zob. R. Dunbar, Człowiek..., dz. cyt., s. 37, 342 i 346-347.

65 Zob. tamże, s. 343 i 348. 
rego samo osiadłe zamieszkiwanie musi zawsze prowadzić do budowy świątyń. Mieszkając $\mathrm{w}$ wiosce, nadal można praktykować religię szamanistyczną (robią tak niektóre osiadłe ludy rolnicze w USA, np. Hopi, gdyż potrzebna jest jedynie pusta przestrzeń do tańca, której tam nie brakuje, choćby jakiś szeroki plac). Ponadto nie ma żadnego powodu, dla którego społeczności zbieracko-łowieckie miałyby nie ustalać jakiegoś wspólnego świętego miejsca (jak jest u australijskich Aborygenów). Badania archeologiczne dowodzą także, że na niektórych stanowiskach neolitycznych wznoszono budowle podobne do świątyń, zanim powstały tam stałe domostwa ${ }^{66}$.

Dlatego autor podaje inny powód, który mógł decydować o pojawieniu się religii hiperdoktrynalnej w kontekście przemiany prowadzonego trybu życia. Otóż sugeruje, że taka (dość nagła) zmiana typu religii była podyktowana wzrostem liczebności grup. Zdaniem Dunbara może występować naturalny graniczny punkt określający liczebność grupy (tj. ok. 500 osób), którego przekroczenie mocno osłabia spójność grupy. Tak więc aby tego uniknąć, musiała nastąpić jakaś radykalna zmiana dotychczasowej organizacji społecznej. Główną rolę ma w niej grać religia hiperdoktrynalna ${ }^{67}$.

Wznoszenie specjalnych budynków wyłącznie dla celów rytualnych wskazuje na przejście ku [...] postaci zrytualizowanej religijności, odmiennej od znacznie mniej formalnych praktyk szamanistycznych. Obecność budynków o przeznaczeniu rytualnym wskazuje na istnienie grupy «specjalistów» - kapłanów, którzy występują w imieniu społeczności, odgrywając specjalne rytuały, zaś pozostali członkowie grupy mogą je tylko obserwowaćo ${ }^{68}$.

Wyznawcy takiego typu religii podlegają odgórnej dyscyplinie nałożonej ze strony hierarchii religijnych specjalistów, którzy oznajmiają, że oto działają w imieniu istot świata duchowego (bogów i świętych). Przez kapłanów są ogłaszane groźby kar w tym świecie i w zaświatach za złą postawę moralną (bogowie bardzo interesują się działaniami ludzi i domagają się danego zachowania). Taki rygor zaś jest uniwersalnie przyjmowany przez całą grupę wyznawców ${ }^{69}$. Można tu również zaproponować inny łańcuch przyczynowo-skutkowy dla przejścia $\mathrm{z}$ jednego do drugiego typu religijności. Otóż przemiana trybu życia z łowiecko-

\footnotetext{
Zob. tamże, s. 343-344.

Zob. tamże, s. 344.

Tamże.

Zob. tamże, s. 345 i 347.
} 
-zbierackiego na rolniczy mogła wynikać przede wszystkim z zachodzących zmian klimatycznych. Lodowiec się wycofał, dzięki czemu było cieplej; w tych warunkach mogło mieć miejsce odkrycie przez kromaniończyków nowego trybu życia, który dawał większe możliwości życiowe - uprawa roli jest wydajniejsza i bezpieczniejsza. Nowy, osiadły tryb życia skutkował zwiększeniem liczebności poszczególnych grup, np. ze 150 do 500 . To zaś spowodowało już zmiany w mentalności, $\mathrm{w}$ tym $\mathrm{w}$ sposobie myślenia na temat form praktykowania religijności. Wtedy powstawały religie soteriologiczne, jak np. ok. 5000 lat temu mazdaizm, religia starożytnych Irańczyków.

Liczba 500 (jako punkt krytyczny liczebności grupy) nie jest przypadkowa. Autor przytacza wynik badania, które mówi, że właśnie powyżej tej liczby osób ma miejsce formowanie się specjalizacji zawodowych (m.in. garncarza, rzemieślnika, karczmarza, najemnika i urzędnika). Tak więc poza wyłonieniem się kapłanów następuje w takiej liczniejszej społeczności wzrost złożoności kultury materialnej (tj. nowe rodzaje ubrań i biżuterii, jak też wszelkiej wytwórczości). Mogła ona stanowić rozmyślną odpowiedź na ryzyko rozpadu danej społeczności, zwiększające się wraz ze wzrostem liczebności grupy (posiadanie bogatszego zestawu produktów kultury pomogło „definiować” daną społeczność, tym samym przeciwdziałało jej dezintegracji ${ }^{70}$. Jednak znaczenie religii hiperdoktrynalnej jest wyjątkowe. W odniesieniu do dużych grup religijnych Dunbar pisze:

Osoby będące aktywnymi wyznawcami Boga chętniej działają prospołecznie i postępują w zgodzie z regułami współżycia społecznego niż pozostali członkowie grupy. [...] Nie powinniśmy również zapominać, w jak dużym stopniu poglądy religijne, będące złożoną mieszaniną światopoglądu, opowieści o początku i przepisów moralnych, wytwarzają poczucie jedności i członkostwa we wspólnocie. Pod tym względem wydają się one opierać na tych samych elementarnych wymiarach, które charakteryzują przyjaźń. Wydaje się [...], że fundamentalne procesy psychologiczne leżące u podstaw przyjaźni zostały wykorzystane - przy powstaniu religii doktrynalnych - do wytworzenia poczucia przynależności do wirtualnej wspólnoty, której członkami jest znaczna liczba zupełnie obcych osób ${ }^{71}$.

\footnotetext{
70 Zob. tamże, s. 342 i 344 .

71 Tamże, s. 346.
} 
Należy zauważyć, że jest to jednak wątpliwe; silniejsze więzy pomiędzy członkami danej grupy były w paleolicie; lepiej mówić o ekstrapolacji spontanicznych więzów osobowych na szersze kręgi społeczne, stąd religie nowego typu postulowały m.in. miłość bliźniego. Dunbar sądzi, że cechą większości religii hiperdoktrynalnych jest złudzenie powiązania rodzinnego członków wspólnoty. Wirtualne pokrewieństwo pełni rolę spajania grupy (tak pojawiły się określenia innych osób z grona wyznawców tej samej religii jak: ojciec, brat, matka, siostra ${ }^{72}$. Trzeba podkreślić, że nie jest to złudzenie, gdyż ludzie we wspólnocie, np. narodowej, są połączeni realnymi więzami, łączy ich m.in. ziemia, język, historia itd.

Następstwem przejścia od religii szamanistycznej do hiperdoktrynalnej jest zmiana intensywności i częstości spotkań religijnych. W religii szamanistycznej angażujące wyznawców tańce transowe są organizowane nieregularnie (tylko wtedy, gdy uzna się to za konieczne, w cyklu mniej więcej miesięcznym). W religii hiperdoktrynalnej ceremonie religijne są zwoływane częściej (zwykle w cyklu tygodniowym) i są mniej intensywne emocjonalnie. Według autora wynika to $\mathrm{z}$ tego, że częste odbywanie stanów transowych jest zbyt stresogenne dla ludzi. W przypadku dużych społeczności (tj. narażonych na wyższy poziom napięć społecznych) lepiej stosować krótszy odstęp między spotkaniami religijnymi. Większa częstotliwość spotkań implikuje obniżenie zaangażowania emocjonalnego wiernych (a uwidacznia się to oddzieleniem religijnego specjalisty - kapłana - od wiernych, który osobiście wykonuje wyczerpujący rytuał ${ }^{73}$.

Mimo istniejących różnic między tymi dwoma typami religii można wskazać cechy, które świadczą, że religie hiperdoktrynalne nie odcięły się całkiem od swoich dawnych szamanistycznych korzeni. Otóż po pierwsze, w religiach hiperdoktrynalnych teologia racjonalistyczna oraz kontrola polityczna narzucona ze strony kapłanów są nierzadko podważane (przejawem tego jest formowanie się heretyckich sekt). Wiąże się to ściśle $\mathrm{z}$ charakterem religii szamanistycznej - nie stanowi systemu hierarchii z zamkniętym zbiorem przekonań religijnych, bo uzależnia je od emocjonalnych potrzeb jednostek. Dunbar sądzi, że takie tendencje do wyłomu względem istniejących systemów wierzeń miały ogromne znaczenie dla ukształtowania nowych, samodzielnych religii (dotyczy to chrześcijaństwa i islamu, na których rozwój ogromny wpływ miał judaizm). Po drugie, występujący $\mathrm{w}$ religiach hiperdoktrynalnych charyzmatyczni kapłani przywodzą tu

Zob. tamże.

Zob. tamże, s. 344-345. 
na myśl postacie szamanów ${ }^{74}$. Po trzecie, religie hiperdoktrynalne praktykujące w ramach rytuału śpiew oraz taniec swoją formą bardzo przypominają praktyki szamanistyczne. Brytyjski antropolog opisuje chrześcijan zielonoświątkowców:

Muzycy, chór i pastor tworzą tam coraz bardziej intensywny i poruszający wir muzyczny, który stopniowo, jednego po drugim, porywa zgromadzonych, aż poczują ekscytację i każdy będzie machał rękami, poruszał całym ciałem i wykrzykiwał w odpowiednich momentach «Amen!» i «Alleluja!». Niektórzy osiągają stany podobne do transu ${ }^{75}$.

Ponadto przytacza tu przykład zrównania znaczenia tańca wśród tych dwóch typów religii:

Taniec jest oczywiście powszechnie wykorzystywany w rytuałach zarówno społeczności tradycyjnych (wspomnijmy transowe tańce Buszmenów !Kung), jak i dojrzałych religii (choćby judaistyczni kapłani tańczący przed Arką Przymierza w czasach króla Dawida bądź dziś, ponad dwa i pół tysiąca lat później, kołyszący taniec dabtarów i diakonów w koptyjskim Kościele etiopskim). [...] taniec był bardzo świadomie wykorzystywany do wywołania stanów euforii i transu przez zakon «wirujących derwiszów» w islamie sufickim - w tym przypadku tancerze synchronicznie kręcą się wkoło [...] dopóki nie wpadną $\mathrm{w}$ stan zbliżony do transu ${ }^{76}$.

Jednak należy zauważyć, że jest to argument za tym, iż są jakieś zasadnicze aspekty religii, które występują we wszystkich jej odmianach.

\section{Zakończenie}

Dunbar przeprowadził analizę zachowań religijnych (religii) pod kątem ich wpływu na poprawę przystosowania się ludzi do trudnych warunków życia w ich środowisku. Religie pierwotne, szamanistyczne, wyewoluowały jako mechanizm wzrostu spójności grupy i zdolności do wzajemnego poświęcenia się ludzi $\mathrm{w}$ grupach. Dunbar zwrócił szczególną uwagę na podnoszenie poziomu endor-

\footnotetext{
74 Zob. tamże, s. 347-348.

75 R. Dunbar, Nowa..., dz. cyt., s. 168.

76 Tamże.
} 
fin w mózgu dzięki tańcom transowym, muzyce i śpiewie. Ponadto wskazał, że wszystkie religie (w tym późniejsze, hiperdoktrynalne, różniące się w formie od religii szamanistycznych) pomagają ludziom radzić sobie w sytuacjach granicznych (w szczególności śmierci - łagodzą ból po stracie bliskich osób). Argumenty autora wskazują, że religie pełnią funkcje adaptacyjne, chociaż nie określa on religii wprost mianem „adaptacji”. Wyróżnił on adaptacyjne funkcje psychofarmakologiczne (pozytywny wpływ m.in. na stan zdrowia psychicznego) i społeczne (poprawa integralności grupy, tworzenie więzi międzyludzkich, budowanie wspólnoty społecznej).

W artykule wskazano kilka uproszczeń lub błędów, które znaleźć można w rozważaniach brytyjskiego antropologa. Dunbar błędnie utożsamił religię z magią, a tymczasem, jak pokazano, różnią się one diametralnie. Ograniczył przyczynę planowanych pochówków do wiary w życie pozagrobowe. Zupełnie pominął zaś fakt oddawania w ten sposób czci osobom zmarłym. Jak się wydaje, przecenił rolę endorfin w mózgu jako istotowego efektu zachowań religijnych. Nie zwrócił zatem uwagi na możliwość istnienia w takim przypadku określonych substytutów religii. Nie rozwiązał wreszcie sprzeczności polegającej na tym, że jak twierdzi - religie wymagają intencjonalności drugiego stopnia, a jednocześnie język rozwinął się później niż one, przy intencjonalności czwartego stopnia. Nie wprowadził np. pojęcia protojęzyka, które jest tu pomocne; nie rozróżnił hipotetycznych religii uzależnionych od stopnia rozwoju języka: językowych i bezjęzykowych. Autor nie zakładał również innych ewentualnych przyczyn przejścia od religii szamanistycznych do hiperdoktrynalnych. Nie uwzględnił np. wpływu zmian klimatycznych na wynalezienie rolnictwa, a wraz z nim nowej mentalności, w tym odmiennych zachowań religijnych. Uprościł znaczenie określonych pojęć i ich rolę w religii (np. pojęcie zbawienia, rola modlitwy). Pominął biologiczne pojęcie adaptacji i jego definicję, choć - jego zdaniem - religia musi pełnić funkcje przystosowawcze). W jego dziełach zabrakło również polemiki z konkurencyjnymi stanowiskami. A co więcej, nie wsparł swych tez, odwołując się do podobnych koncepcji ${ }^{77}$.

77 Na temat religii jako adaptacji zob. W. Burkert, Stwarzanie świętości. Ślady biologii we wczesnych wierzeniach religijnych, tłum. L. Trzcionkowski, Kraków 2006; E.O. Wilson, Konsiliencja. Jedność wiedzy, tłum. J. Mikos, Poznań 2002; E.O. Wilson, O naturze ludzkiej, tłum. B. Szacka, Warszawa 1988; E.O. Wilson, The Social Conquest of Earth, Liveright, New York 2013; E.O. Wilson, Znaczenie ludzkiego istnienia, tłum. B. Baran, Warszawa 2016. 
Pomimo tych mankamentów oryginalność propozycji Dunbara sprawia, że jest on autorem wartym uwagi, również z perspektywy filozoficznej. Można go też traktować (choć nieformalnie) jako jednego z badaczy nowej dyscypliny naukowej, którą jest religiologia ewolucyjna. Jej celem jest badanie istoty zjawiska religii (m.in. jej genezy i pełnionych funkcji) na gruncie neodarwinowskiej teorii ewolucji.

\section{Bibliografia}

Atran S., Ewolucyjny krajobraz religii, tłum. M. Kolan, Kraków 2013.

Boyer P., I człowiek stworzył bogów... Jak powstała religia?, tłum. K. Szeżyńska-Maćkowiak, Warszawa 2005.

Burkert W., Stwarzanie świętości. Ślady biologii we wczesnych wierzeniach religijnych, tłum. L. Trzcionkowski, Kraków 2006.

Dawkins R., Bóg urojony, tłum. P.J. Szwajcer, Warszawa 2007.

Dennett D.C., Odczarowanie. Religia jako zjawisko naturalne, tłum. B. Stanosz, Warszawa 2008.

Dunbar R., Człowiek - biografia, tłum. Ł. Lamża, Kraków 2016.

Dunbar R., Nowa historia ewolucji człowieka, tłum. B. Kucharzyk, Kraków 2014. Swienko H., Religia i religie, Warszawa 1981.

Wilson E.O., Konsiliencja. Jedność wiedzy, tłum. J. Mikos, Poznań 2002.

Wilson E.O., O naturze ludzkiej, tłum. B. Szacka, Warszawa 1988.

Wilson E.O., The Social Conquest of Earth, Liveright, New York 2013.

Wilson E.O., Znaczenie ludzkiego istnienia, tłum. B. Baran, Warszawa 2016.

Wolniewicz B., O istocie religii, w: tegoż, Filozofia i wartości, Warszawa 1993.

Wolniewicz B., O związku myślenia $z$ językiem (Tezy), „Przegląd Filozoficzny Nowa Seria" 2018, nr 3(107).

\section{Streszczenie}

Dunbar reprezentuje nurt ewolucyjnych badaczy religii, którzy sądzą, że religia pełni funkcje adaptacyjne u człowieka. W artykule prezentuje się jego argu- 
menty na rzecz tezy, że zachowania religijne (religia) w szczególności sprzyjają tworzeniu wspólnot społecznych i pozytywnie wpływają na zdrowie psychiczne jednostek (m.in. koją ból po śmierci bliskich). Dunbar przeanalizował główne funkcje religii szamanistycznej, stanowiącej zaczątek późniejszych religii (w tym hiperdoktrynalnych, jak np. judaizm, katolicyzm, protestantyzm i islam). Rytualne tańce transowe hipotetycznie wpływały na produkcję endorfin w mózgu, co w efekcie sprzyjało spajaniu grup i poświęcaniu się innym, czyli sprzyjało przetrwaniu danej społeczności. Te same funkcje, choć przy odmiennych cechach rytuału, pełnią także wszystkie religie współczesne. W artykule są poruszone też inne zagadnienia: problem określenia momentu pojawienia się religii w dziejach człowieka, kwestia podobieństw oraz różnic w religiach szamanistycznych i hiperdoktrynalnych (ponadto przyczyny przejścia jednej formy religijności w drugą), domniemany początek wiary w życie pozagrobowe, podział religii z uwagi na stopień intencjonalności, problem istnienia języka w świetle wyewoluowania religii, artefakty religijne jako świadectwa religijności człowieka. Dunbar - jako nieformalny religiolog ewolucyjny - wzbogaca coraz liczniejsze badania nad istotą, genezą i funkcją religii, które są podejmowane przez neodarwinowskich teoretyków (biologów, antropologów, psychologów i kognitywistów).

Słowa kluczowe: ewolucja religii, funkcje adaptacyjne religii, religie szamanistyczne, religie hiperdoktrynalne, intencjonalność

\section{Summary}

Dunbar represents the evolutionary current of religion researchers who believe that religion performs adaptive functions in man. The article presents his arguments in favor of the thesis that religious behavior (religion) in particular promotes the creation of social communities and positively affects the mental health of individuals (including soothing pain after the death of loved ones). Dunbar analyzed the main functions of the shamanic religion, which was the beginning of later religions (including hyperdoctrinal ones, such as Judaism, Catholicism, Protestantism and Islam). Ritual trance dances hypothetically influenced the production of endorphins in the brain, which in effect favored the joining of groups and dedication to others, i.e. favored the survival of a given commu- 
nity. All modern religions perform the same functions, although with different features of the ritual. The article also addresses other issues: the problem of determining the moment of the appearance of religion in human history, the issue of similarities and differences in shamanic and hyperdoctrinal religions (in addition, the reasons for the transition of one form of religion to another), the alleged beginning of faith in the afterlife, the division of religions due to the degree of intentionality, the problem of language existence in the light of the evolution of religion, religious artifacts as the evidence of human religiosity. Dunbar - as an informal evolutionary religiologist - enriches the ever-increasing research into the essence, genesis and function of religion, which is undertaken by neo-Darwinian theorists (biologists, anthropologists, psychologists and cognitive scientists).

Key words: evolution of religion, adaptive functions of religions, shamanic religions, hyperdoctrinal religions, intentionality 